\title{
sciendo
}

CIVIL AND ENVIRONMENTAL ENGINEERING REPORTS

E-ISSN 2450-8594

CEER 2018; 28 (2): 186-195

DOI: $10.2478 /$ ceer-2018-0029

Original Research Article

\section{MEASUREMENT DATA PROCESSING WITH THE USE OF ART NETWORKS}

\author{
Maria MRÓWCZYŃSKA ${ }^{1}$, Jacek SZTUBECKI² \\ ${ }^{1}$ University of Zielona Gora, Zielona Góra, Poland \\ ${ }^{2}$ University of Technology and Life Sciences in Bydgoszcz, Bydgoszcz, Poland
}

\begin{abstract}
ART (Adaptive Resonance Theory) networks were invented in the 1990s as a new approach to the problem of image classification and recognition. ART networks belong to the group of resonance networks, which are trained without supervision. The paper presents the basic principles for creating and training ART networks, including the possibility of using this type of network for solving problems of predicting and processing measurement data, especially data obtained from geodesic monitoring. In the first stage of the process of creating a prediction model, a preliminary analysis of measurement data was carried out. It was aimed at detecting outliers because of their strong impact on the quality of the final model. Next, an ART network was used to predict the values of the vertical displacements of points of measurement and control networks stabilized on the inner and outer walls of an engineering object.
\end{abstract}

Keywords: ART neural networks, prediction model, vertical displacements

\footnotetext{
1 Corresponding author: University of Zielona Gora, Faculty of Civil, Architecture and Environmental Engineering, Z. Szafrana st 1, 65-516 Zielona Góra, Poland, e-mail: m.mrowczynska@ib.uz.zgora.pl, tel.+48683282636

${ }^{2}$ University of Technology and Life Sciences in Bydgoszcz, Faculty of Civil and Environmental Engineering and Architecture, S. Kaliskiego ave. 7, 85-796 Bydgoszcz, Poland, e-mail: jaceksz@utp.edu.pl, tel.+48661567541
} 


\section{INTRODUCTION}

Artificial intelligence (AI) is a field of science that mainly concentrates on searching for methods for solving problems that imitate processes occurring in the brain. For this reason AI algorithms are able to learn, draw conclusions, generalize the acquired knowledge and foresee or predict the results of the actions taken $[6,10,11,13]$. Neural networks created by scientists can be trained under supervision and without supervision. An example of a network trained without supervision (without a teacher) is the ART (Adaptive Resonance Theory) network used in this paper.

ART neural networks were invented by Grossberg and Carpenter [2] as a new approach to solving image classification and recognition problems. ART networks belong to the group of resonance networks, which are trained without supervision. It is possible to distinguish three types of ART networks: network ART 1, which is mainly used for analysing binary images, and networks ART 2 and ART 3, which are used for analysing analogue images [10].

In comparison with the other neural networks used for data and image classification and recognition, in the case of ART networks it is not necessary to repeat the training process after new patterns are introduced into the network. This approach is possible because the network preserves previously acquired knowledge and can continue the learning process for new data [1]. In general, this type of network consists of two layers: the lower input layer, whose task is to register input signals and to compare them with the previously registered patterns, and the upper output layer, where features are analysed by determining the weighted sum of inputs and recognizing images. The final decision is made based on competition between neurons $[4,13]$.

ART-type networks have been frequently modified by a number of scientists for the purpose of solving specific problems [1,3], including problems from the field of broadly understood geodesy and cartography [7,14]. The paper presents the problem of using ART neural networks for identifying and classifying vertical displacements of points of measurement and control networks stabilized on a public building. The building had a masonry structure with alternately arranged prefabricated concrete floor slabs. Periodic measurements aimed at determining the values of vertical displacements were carried out with the precision levelling method in the years 2006-2014.

\section{ART NETWORK TRAINING AND OPERATION SCHEME}

ART neural networks are trained without supervision and based on the adaptation resonance theory. A typical ART network architecture (Fig. 1) was presented by 
Carpenter and Grossberg [2]. A block scheme of the network represents sets of particular neurons, and the network itself consists of two layers: the comparing layer and the recognizing layer. The first layer (the comparing layer $P$ ) with $n$ binary neurons and a step function as an activation function compares the input data with the data stored in the memory of the algorithm. The second layer (the recognizing layer $R$ ) with $m$ neurons, which operate in the WTA (Winner Takes All) mode, classifies the input data [8].

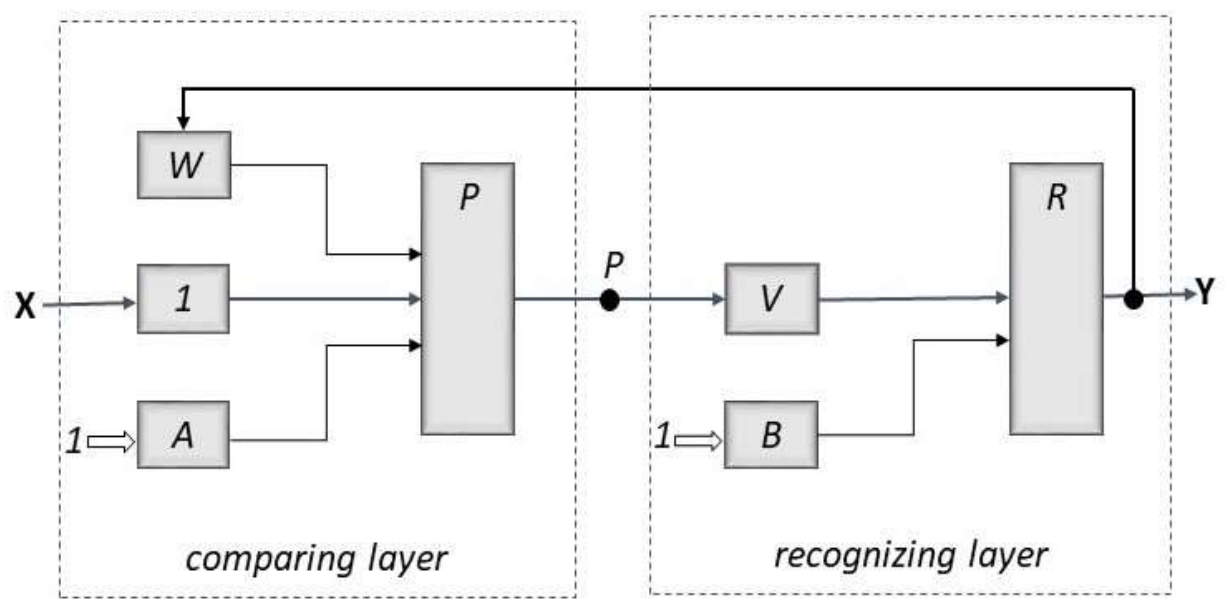

Fig. 1. The block structure of an ART network [prepared by the authors, based on Osowski

The particular blocks shown in Fig. 1 represent the sets of neurons $(\mathbf{P}, \mathbf{R})$, the weight matrixes $(\mathbf{W}, \mathbf{V}, \mathbf{A}, \mathbf{B})$ and the identity matrix $\mathbf{1}$. The neurons in the comparing layer $P$ are connected with the input set $\mathbf{X}$ and by the weight matrix

$\mathbf{W}$ defined as $\mathbf{W}=\left[\begin{array}{cccc}w_{11} & w_{12} & \cdots & w_{1 m} \\ w_{21} & w_{22} & \cdots & w_{2 m} \\ \cdots & \cdots & \cdots & \cdots \\ w_{n 1} & w_{n 2} & \cdots & w_{n m}\end{array}\right]$ with all neurons of the layer $R$.

In the recognizing layer neurons operate in the WTA mode, so the competition is won by the $i^{\text {th }}$ neuron with the highest value of the weighted adder net defined as [8]:

$$
\operatorname{net}_{i}=\sum_{i=1}^{n} v_{i j} p_{j}+b_{i}
$$


where: $\mathbf{P}=\left[\begin{array}{c}p_{1} \\ p_{2} \\ \vdots \\ p_{n}\end{array}\right]-$ the vector of the layer $P, \mathbf{B}=\left[\begin{array}{c}b_{1} \\ b_{2} \\ \vdots \\ b_{m}\end{array}\right]$ - the vector of the polarization signal, $\mathbf{V}=\left[\begin{array}{cccc}v_{11} & v_{12} & \cdots & v_{1 n} \\ v_{21} & v_{22} & \cdots & v_{2 n} \\ \cdots & \cdots & \cdots & \cdots \\ v_{m 1} & v_{m 1} & \cdots & v_{m n}\end{array}\right]$ - the weight matrix.

Since the ART network is recurrent, the $i^{\text {th }}$ neuron in the layer $R$ takes over the signal from the layer $P$ through the weights $\mathbf{V}$, and after winning the competition against the other neurons of this layer, it sends its signal back through the weights W to the layer $P$. While using the ART network for solving the problems in question, it is necessary to pay special attention to the selection of values of the vectors $\mathbf{A}$ and $\mathbf{B}$, which do not undergo the training process, but change the values of their components during the operation of the network. Using specifically determined values of these vectors, it is possible to stop the operation of particular neurons and eliminate them from competition against the other neurons in the layer $R$. The process of competition between neurons in the recognizing layer lasts until victorious neurons representing the data pattern are determined, which satisfy the condition of adaptation to the input vector $\mathbf{X}$ written as [8]:

$$
\varepsilon \geq \varepsilon_{\min }
$$

where $\varepsilon$ is the conformity factor calculated as the numerical ratio between the sum of individual neurons of the layer $P$ and individual values of the input vector $\mathbf{X}$, and $\varepsilon_{\min }$ is a value chosen a priori by the user of the network. A general scheme of the operation of the network consists of five stages, which are presented in Fig. 2.

\section{NUMERICAL EXAMPLE}

The object where the measurements were carried out is a four-floor administration-office building with a basement. On the inner and outer walls of the building there are scratches and cracks that may indicate changes that put at risk the stability of the building's structure. In the case of this type of signal, geodesic monitoring is very important. It should be carefully planned and carried out, also with the use new technology, both during measurements and while processing the results $[5,12,15]$. 
The paper presents the results of research aimed at determining uneven settlement of the object and predicting it with the use of an ART network. In order to do this, periodic measurements were carried out on measurement and control networks set up outside and inside the building (Fig. 3a, 3b). The network set up outside the building consisted of 10 points, and the network inside the building consisted of 6 points. Periodic measurements were carried out with the precision levelling method in the years 2006-2014. During that time 6 periodic measurements were carried out.

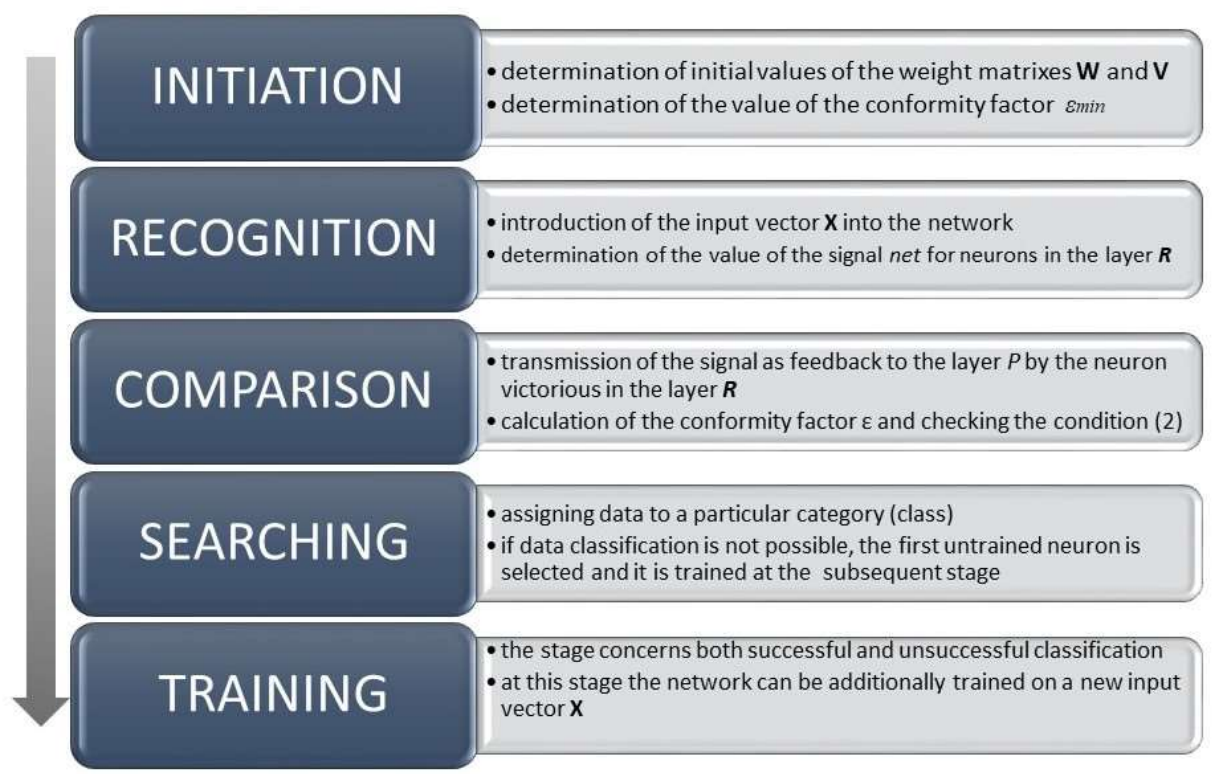

Fig. 2. The block structure of the ART network [prepared by the authors]

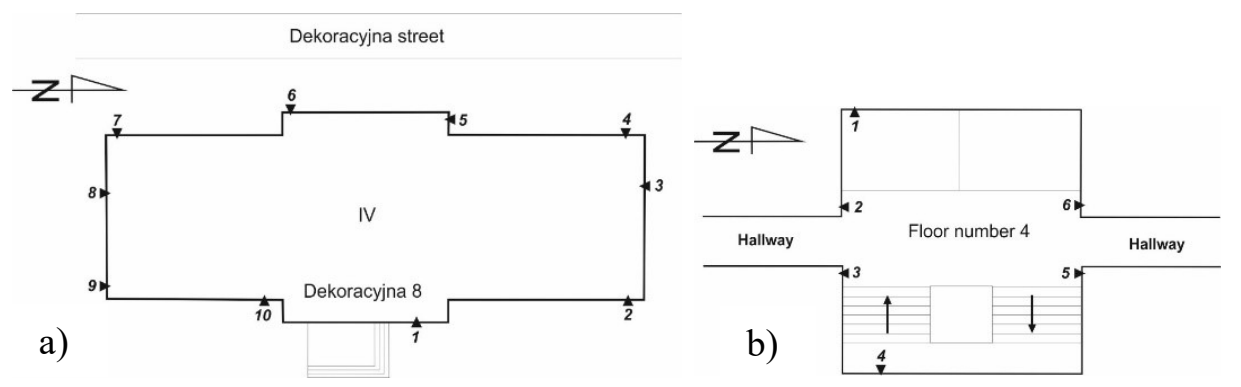

Fig. 3. A sketch of the measurement and control network set up outside (a) and inside (b) the building

All measurements and calculations were compared with the zero measurement carried out in June 2006. During the process aimed at determining vertical 
displacements of points of the measurement and control network, mutually stable points were identified, which define the reference system. This was based on the algorithm shown in Fig. 4. The displacements determined for the measurement points are relative in character and they provide sufficiently precise information about the stability of the building [9].

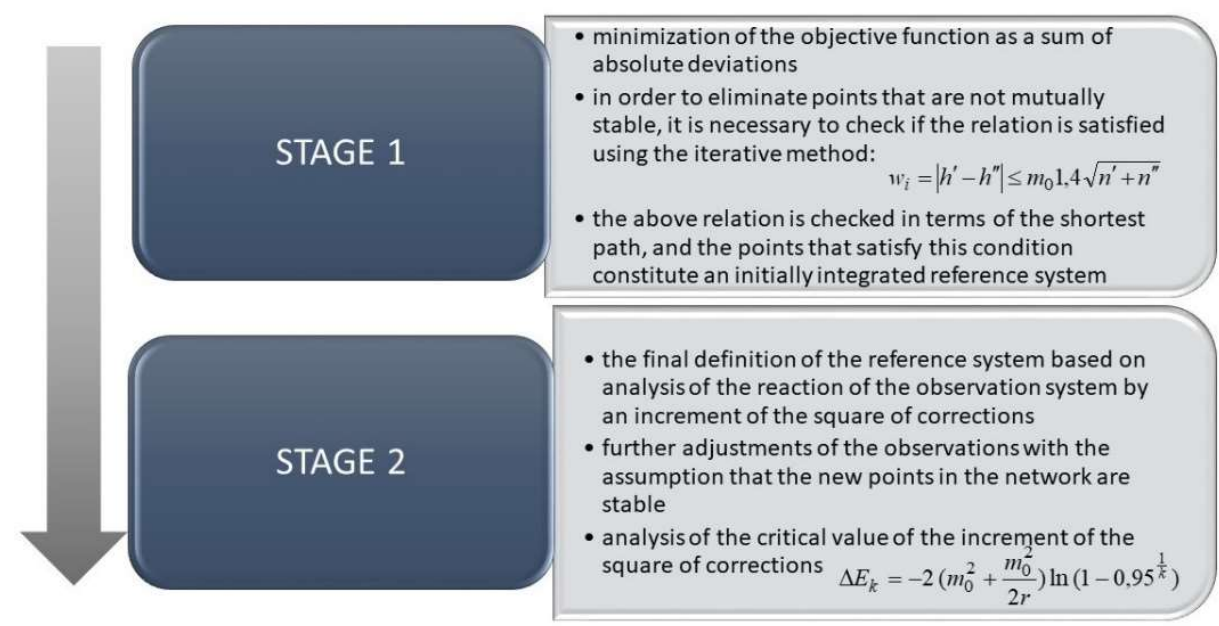

Fig. 4. A scheme for defining the reference system

Table 1. A comparison between the vertical displacements measured and the ones obtained with the use of the ART network

\begin{tabular}{|c|c|c|c|c|c|c|}
\hline \multirow{2}{*}{$\begin{array}{c}\text { Point } \\
\text { No. }\end{array}$} & \multicolumn{7}{|c|}{ Vertical displacements } \\
\cline { 2 - 7 } & \multicolumn{3}{|c|}{ Inner network } & \multicolumn{3}{c|}{ Outer network } \\
\cline { 2 - 7 } & $\begin{array}{c}06.2006- \\
12.2006 \\
{[\mathrm{~mm}]}\end{array}$ & $\begin{array}{c}06.2006- \\
08.2014 \\
{[\mathrm{~mm}]}\end{array}$ & $\begin{array}{c}06.2006- \\
08.2014 \\
{[\mathrm{~mm}]} \\
\text { prediction }\end{array}$ & $\begin{array}{c}06.2006- \\
12.2006 \\
{[\mathrm{~mm}]}\end{array}$ & $\begin{array}{c}06.2006- \\
08.2014 \\
{[\mathrm{~mm}]}\end{array}$ & $\begin{array}{c}06.2006- \\
08.2014 \\
{[\mathrm{~mm}]} \\
\text { prediction }\end{array}$ \\
\hline 1 & -0.19 & 0.45 & 0.63 & -0.22 & -0.01 & 0.03 \\
\hline 2 & 0.00 & 0.07 & 0.12 & -0.50 & -1.36 & -1.45 \\
\hline 3 & -0.10 & -0.08 & 0.05 & -0.78 & -2.11 & -2.18 \\
\hline 4 & -0.05 & 1.18 & 1.25 & -0.96 & -2.93 & -2.64 \\
\hline 5 & 0.18 & 0.46 & 0.34 & -0.17 & -1.13 & -1.05 \\
\hline 6 & 0.07 & 0.01 & 0.08 & -0.30 & -0.49 & -0.35 \\
\hline 7 & & & & 0.04 & -0.46 & -0.52 \\
\hline 8 & & & & 0.00 & 0.01 & 0.11 \\
\hline 9 & & & & 0.02 & 0.00 & 0.05 \\
\hline 10 & & & & -0.09 & 0.41 & 0.25 \\
\hline
\end{tabular}

The analysis of the measurement data and calculation results made it possible to state that in the years 2006-2014 the uneven settlement presented in Table 1 
ranged from -2.93 to $0.41 \mathrm{~mm}$ (outer network) and from -0.19 to $1.18 \mathrm{~mm}$ (inner network).

Based on the results obtained, an attempt was made to use the ART network for predicting vertical displacements. The prediction was carried out for the final measurement period of August 2014. The results of the prediction for the outer network and the inner network are presented in Figures 5 and 6.

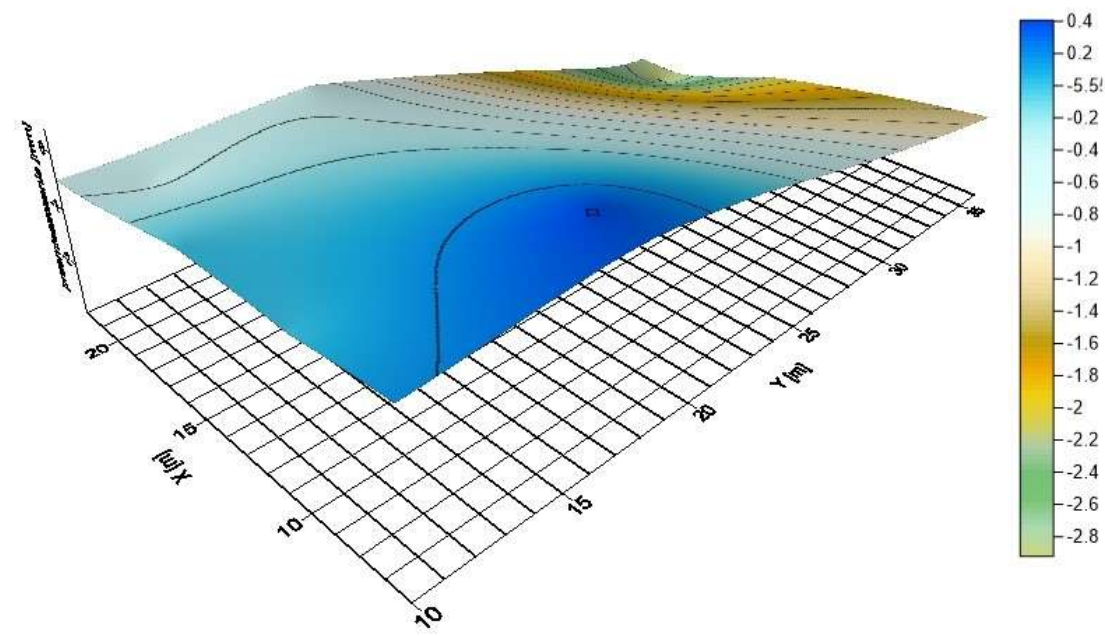

Fig. 5. Prediction of vertical displacements (outer network)

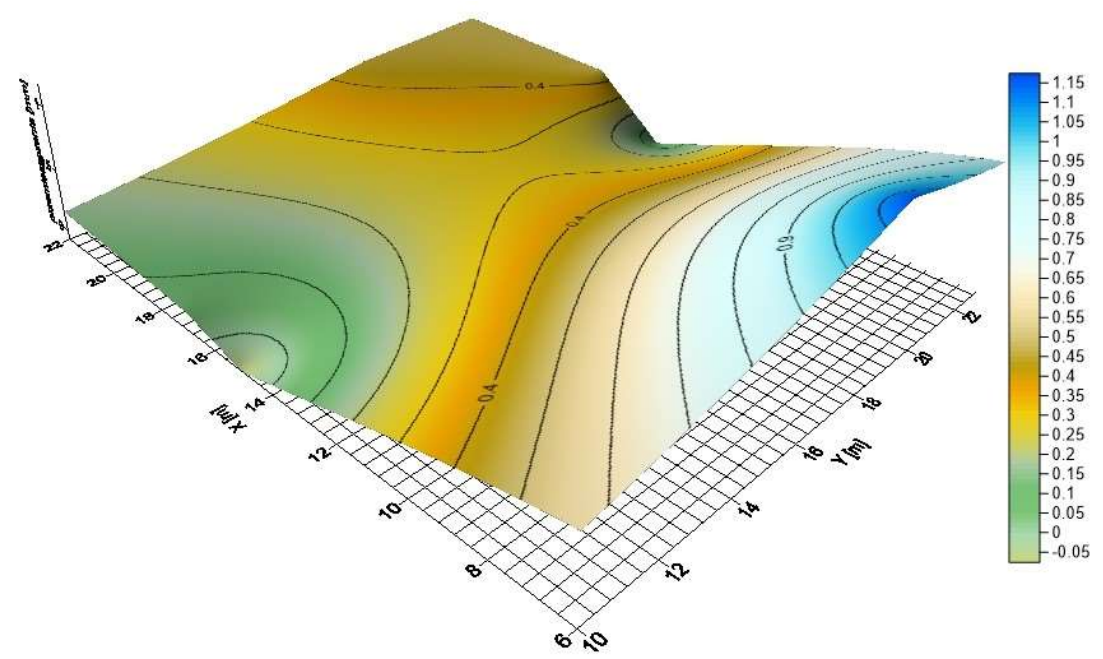

Fig. 6. Prediction of vertical displacements (inner network) 
The accuracy of the prediction of vertical displacements was characterized for both networks by the mean error. For the inner network this error was $\pm 0,14 \mathrm{~mm}$, and the distribution of errors is shown in Fig. 7a. The mean error for the outer network amounted to $\pm 0,04 \mathrm{~mm}$, the distribution of errors is shown in Fig. $7 \mathrm{~b}$. As can be seen, the prediction was carried out with sufficient accuracy, which is on the same level as the accuracy of the measurements. The only disadvantage of the results is the generalization of the network training process, which is probably the reason why the tendency of changes in the negative direction at one point of the inner network remained unnoticed.
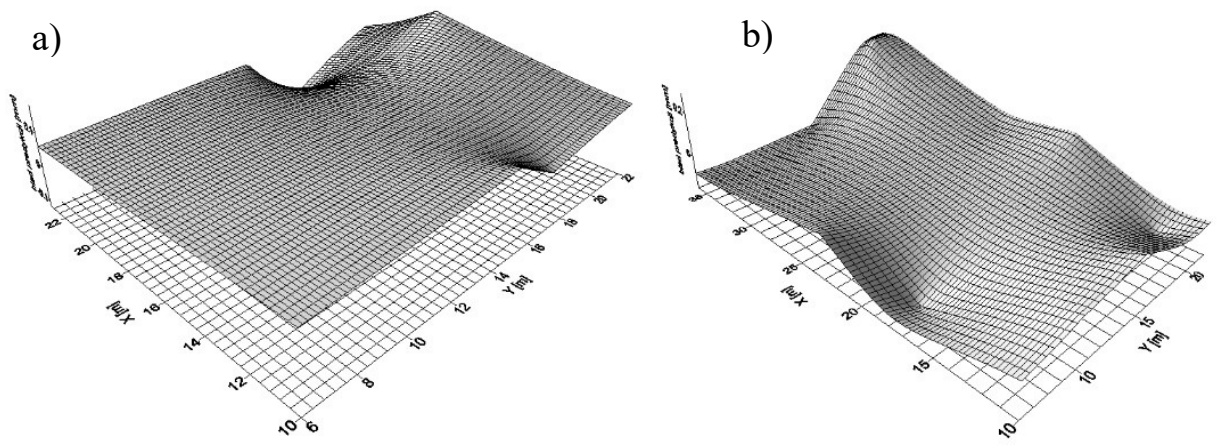

Fig. 7. The distribution of errors for the outer network (a) and the inner network (b)

\section{CONCLUSIONS}

The article presents the possibility of using an ART-type network, based on the resonance theory, for predicting vertical displacements of points of measurement and control networks located inside and outside a building that is at risk of uneven settlement.

In the case of buildings where this phenomenon is likely to occur, it is important to carry out geodesic measurements periodically at equal time intervals. This kind of geodesic monitoring of engineering objects can be helpful in making decisions about the necessity to carry out protective work or renovations in these objects.

The use of the ART network was preceded with a calculation procedure for determining vertical displacements. One of its elements is definition of a reference system based on minimization of absolute deviations. This is very favourable from the practical point of view because the set of mutually stable points is determined with the smallest value of the sum of the squares of corrections to the observations, which decreases the probability of occurrence of a type II error.

On the basis of the results, it is possible to say that ART neural networks can be used for predicting vertical displacements of points of a measurement and control 
network. However, it should be noticed that the values of prediction errors strongly depend on the correctness of the training process and the conditions adopted a priori for the termination of the training process. Research using artificial intelligence and the theory of structural mechanics makes it possible to predict changes in engineering objects and thus to anticipate their damage.

\section{REFERENES}

1. Bielecki A, Wójcik M.: Hybrid system of ART and RBF neural networks for online clustering, Applied Soft Computing 58, pp. 1-10, 2017.

2. Carpenter G.A., Grossberga S.: Adaptive resonance theory: Self-organizing networks for stable learning, recognition and prediction, Handbook of Neural Computation, Bristol 1997.

3. Dudek R.: Przetwarzanie danych $w$ opartych na podobieństwie metodach prognozowania przebiegów dobowych zapotrzebowania na moc elektryczna, Przegląd Elektrotechniczny, no. 9, pp. 15-19, 2006.

4. Howard A., Padgett C., Liege C.: A multi-stage neural network for automatic target detection, International Joint Conference of Neural Networks, Anchorage, Alaska 1998.

5. Kazak J., Świąder M., Szewrański Sz.: GEO-environmental indicators in Strategic Environmental Assessment, acta scientiarum polonorum-formatio circumiectus, Vol. 16 (2), p.123-135, 2017.

6. Korbicz J., Obuchowicz A., Uciński D.: Sztuczne sieci neuronowe. Podstawy i zastosowania, Akademicka Oficyna Wydawnicza PLJ, Warsaw 1994.

7. Li P., Chen B., Li Z., Zheng X., Wu H., Jing L., Lee K.: A Monte Carlo simulation based two-stage adaptive resonance theory mapping approach for offshore oil spill vulnerability index classification, Marine Pollution Bulletin 86, pp. 434-442, 2014.

8. Osowski S.: Sieci neuronowe, Oficyna Wydawnicza Politechniki Warszawskiej, Warsaw 1996.

9. Prószyński W., Kwaśniak B.: Podstawy geodezyjnego wyznaczania przemieszczén, Oficyna Wydawnicza Politechniki Warszawskiej, Warsaw 2006.

10. Rutkowski L.: Metody i techniki sztucznej inteligencji, Wydawnictwo Naukowe PWN, Warsaw 2009.

11. Sieci neuronowe, edit. M. Nałęcz, Akademicka Oficyna Wydawnicza EXIT, Warsaw 2000.

12. Skrzypczak I., Kogut J., Kokoszka W., Zientek D., Monitoring of landslide areas with the use of contemporary methods of measuring and mapping, Civil and Environmental Engineering Reports, Vol. 24 (1), p.69-82, 2017. 
13. Tadeusiewicz R.: Sieci neuronowe, Akademicka Oficyna Wydawnicza, Warsaw 1993.

14. Wuest B., Zhang Y.: Region based segmentation of quickbird imagery through fuzzy integration, The International Archives of the Photogrammetry, Remote Sensing and Spatial Information Sciences, Vol. XXXVII, Part B7, Beijing 2008.

15. Zaczek-Peplinska J., Pasik M., Popielski P.: Geodezyjny monitoring obiektów $w$ rejonie oddziaływania budowy tuneli i głębokich wykopów - doświadczenia $i$ wnioski, Acta Scientiarum Polonorum Architectura. Vol. 12 (2), p. 17-31, 2013.

\section{PRZETWARZANIA DANYCH POMIAROWYCH Z WYKORZYSTANIEM SIECI Z REZONANSEM ADAPTACYJNYM ART.}

\section{Streszczenie}

Sieci neuronowe ART (ang. Adaptive Resonance Theory) zostały opracowane w latach 90 ubiegłego wieku, jako nowe podejście w rozwiązywaniu problemów klasyfikacji I rozpoznawaniu obrazów. Sieci ART należą do grupy sieci rezonansowych, których uczenie prowadzone jest $\mathrm{W}$ trybie nie nadzorowanym. W artykule przedstawiono podstawowe zasady budowy i uczenia sieci neuronowych ART wraz z możliwością aplikacji tego rodzaju sieci do rozwiązywania zagadnień predykcji i przetwarzania danych pomiarowych, w szczególności pozyskanych w wyniku prowadzonego monitoringu geodezyjnego. W pierwszym etapie procesu budowy modelu predykcyjnego wykonano wstępną analizę danych pomiarowych związaną z wykrywaniem obserwacji odstających ze względu na ich istotny wpływ na ostateczną jakość modelu. Następnie wykorzystując sieć ART wyznaczono przewidywane wartości przemieszczeń pionowych dla punktów sieci pomiarowo-kontrolnej, zastabilizowanych na wewnętrznych i zewnętrznych ścianach obiektu budowlanego, na których zauważono liczne spękania.

Słowa kluczowe: sieci neuronowe ART, model predykcyjny, przemieszczenia pionowe

Editor received the manuscript 21.06.2018 